\title{
ANALISIS PERHITUNGAN DAN PELAPORAN PAJAK PENGHASILAN PASAL 21 PADA PT. GATRA KALTIM JAYA KOTA BALIKPAPAN
}

\author{
Pandu Dewanata \\ Jantje J. Tinangon \\ Heince R. N. Wokas \\ Fakultas Ekonomi dan Bisnis Jurusan Akuntansi \\ Universitas Sam Ratulangi Manado \\ email : pandu_dewanata29@yahoo.co.id
}

\begin{abstract}
ABSTRAK
Perusahaan sebagai pemotong pajak memiliki peranan yang sangat besar bagi pemerintah. Saat ini tidak sedikit perusahaan yang melaksanakan pemotongan pajak yang tidak sesuai ketentuan yang berlaku. Hal ini disebabkan perusahaan menganggap pajak sebagai biaya sehingga perusahaan akan meminimalkan biaya tersebut untuk mengoptimalkan laba. Oleh karena itu demi kelancaran pemotongan pajak diperlukan kerjasama yang baik antara pemerintah dengan perusahaan. PT. GATRA KALTIM JAYA bergerak dalam bidang perdagangan Umum di Kota Balikpapan telah memberikan kepuasan tertinggi untuk para pelanggan dengan memberikan kualitas produk yang terbaik dan pelayanan inovatif yang tepat waktu. Dalam memberikan kepuasan ini PT. GATRA KALTIM JAYA membutuhkan pegawai-pegawai yang berkualitas agar tujuan perusahaan dapat tercapai. Oleh karena itu sebagai bentuk penghargaan atas jasa yang telah diberikan oleh para pegawainya, perusahaan memberikan kontraprestasi berupa gaji, tunjangan serta beberapa bonus tambahan. Dengan begitu PT. GATRA KALTIM JAYA wajib memotong Pajak Penghasilan Pasal 21 atas gaji pegawainya. Metode analisis yang digunakan dalam penelitian ini adalah penelitian deskriptif. Hasil penelitian yaitu PT. GATRA KALTIM JAYA Balikpapan dalam melakukan perhitungan, pemotongan dan pelaporan Pajak Penghasilan Pasal 21 atas karyawan tetap telah sesuai dengan ketentuan Undang-undang Perpajakan No. 36 Tahun 2008.
\end{abstract}

Kata kunci : pajak, pajak penghasilan, wajib pajak, objek pajak.

\begin{abstract}
Company as a tax cutter has a very big role for the government. Currently there's a few companies that implement the tax deductions are not consistent with applicable regulations. This is caused by the company which considers the tax as a cost that the company will minimize the costs to optimize their profit. It is necessary good cooperation between the government and the company for the sake of continuity of the tax deduction. PT. GATRA KALTIM JAYA engaged in General trading in Balikpapan City has provided the highest satisfaction to the customers by providing the best quality products and innovative services on time. In this satisfying PT. GATRA KALTIM JAYA need qualified employees in order to achieve company goals. Therefore as an appreciation for services provided by its employees, the company gave contra such as wages and salaries also benefits as well as some additional bonuses. So, PT. GATRA KALTIM JAYA is obliged to withhold income tax of salary employees' salary Article 21. The analytical method used in this research is descriptive research. The results are PT. News in Brief KALTIM JAYA Balikpapan in doing calculations, deductions and tax reporting of Income Tax Article 21 of the employee already complianced with the provisions of Law Taxation. No. 36 of 2008.
\end{abstract}

Keywords: tax, income tax, assessable, tax object. 


\title{
PENDAHULUAN
}

\section{Latar Belakang}

Perusahaan sebagai pemotong pajak memiliki peranan yang sangat besar bagi pemerintah. Mengingat saat ini tidak sedikit perusahaan yang melaksanakan pemotongan pajak tidak sesuai ketentuan yang berlaku. Hal ini disebabkan perusahaan menganggap pajak sebagai biaya sehingga perusahaan akan meminimalkan biaya tersebut untuk mengoptimalkan laba. Oleh karena itu demi kelancaran pemotongan pajak diperlukan kerjasama yang baik antara pemerintah dengan perusahaan.

PT. GATRA KALTIM JAYA bergerak dalam bidang perdagangan Umum / Leveransir Distributor dan Dealer Kendaraan Bermotor, termasuk penjualan sparepart kendaraan bermotor serta variasinya, Agen / Perwakilan perusahaan lokal dan luar negeri, penyewaan kendaraan bermotor, pengangkutan, perbengkelan dan kontraktor di Kota Balikpapan telah memberikan kepuasan tertinggi untuk para pelanggan dengan memberikan kualitas produk yang terbaik dan pelayanan inovatif yang tepat waktu. Dalam memberikan kepuasan ini PT. GATRA KALTIM JAYA membutuhkan pegawaipegawai yang berkualitas agar tujuan perusahaan dapat tercapai. Oleh karena itu sebagai bentuk penghargaan atas jasa yang telah diberikan oleh para pegawainya, perusahaan memberikan kontra prestasi berupa gaji, tunjangan serta beberapa bonus tambahan yang disesuaikan dengan kinerjanya. Dengan begitu PT. GATRA KALTIM JAYA wajib memotong Pajak Penghasilan Pasal 21 atas gaji pegawainya, dengan berpedoman pada peraturan perpajakan yang berlaku.

Penulis memilih PT. GATRA KALTIM JAYA karena perusahaan ini merupakan salah satu yang cukup besar di Kalimantan Timur dan memiliki jumlah karyawan yang besar pula. Sehingga menarik untuk dilakukan penelitian mengenai tata cara perusahaan dalam melaksanakan pemotongan, penyetoran, dan pelaporan pajak penghasilan pada karyawan.

\section{Tujuan Penelitian}

Tujuan penelitian ini adalah bagaimana mekanisme perhitungan, pemotongan serta pelaporan pajak penghasilan pasal 21 pada karyawan PT. GATRA KALTIM JAYA menurut Undang-Undang No. 36 Tahun 2008 tentang Pajak Penghasilan?

\section{TINJAUAN PUSTAKA}

\begin{abstract}
Akuntansi
Akuntansi adalah pengukuran, penjabaran, atau pemberian kepastian mengenai informasi yang akan membantu manajer, investor, otoritas pajak dan pembuat keputusan lain untuk membuat alokasi sumber daya keputusan di dalam perusahaan, organisasi, dan lembaga pemerintah. Akuntansi adalah seni dalam mengukur, berkomunikasi dan menginterpretasikan aktivitas keuangan. Secara luas, akuntansi juga dikenal sebagai "bahasa bisnis". Akuntansi bertujuan untuk menyiapkan suatu laporan keuangan yang akurat agar dapat dimanfaatkan oleh para manajer, pengambil kebijakan, dan pihak berkepentingan lainnya, seperti pemegang saham, kreditur, atau pemilik (Harahap, 2005:2)

American Accounting Association, mendefinisikan akuntansi sebagai proses mengidentifikasikan, mengukur, dan melaporkan informasi ekonomi, untuk memungkinkan adanya penilaian dan keputusan yang tegas bagi mereka yang menggunakan informasi tersebut. (Waluyo, 2009:20)

Akuntansi adalah sistem informasi yang mengidentifikasi, mencatat, dan mengkomunikasikan peristiwa ekonomi dari suatu organisasi untuk pengguna yang tertarik. Akuntansi terdiri dari tiga kegiatan dasar itu mengidentifikasi, mencatat, dan mengkomunikasikan peristiwa ekonomi dari suatu organisasi untuk pengguna yang tertarik. Untuk mengidentifikasi peristiwa ekonomi, perusahaan memilih peristiwa ekonomi yang relevan dengan bisnis. (Weygandt, et al 2011)
\end{abstract}


Definisi-definisi diatas menjelaskan akuntansi sebagai suatu seni atau aktivitas jasa dan mengartikan bahwa akuntansi meliputi beragam teknik yang dianggap berguna untuk bidang-bidang tertentu. (Belkaoui, 2011:5)

\section{Konsep Dasar Akuntansi Perpajakan Pajak}

Soemitro menyatakan bahwa, pajak adalah iuran rakyat kepada kas negara berdasarkan undang-undang (yang dapat dipaksakan) dengan tiada mendapat jasa timbal balik (kontraprestasi) yang langsung dapat ditunjukkan, dan yang digunakan untuk membayar pengeluaran umum. (Mardiasmo, 2009:1)

Pajak menurut Andriani yang dikutip oleh Rahayu (2010:22) adalah iuran kepada negara (yang dapat dipaksakan) yang terutang oleh wajib pajak membayarnya menurut peraturan-peraturan dengan tidak mendapat prestasi kembali, yang langsung dapat ditunjuk yang kegunaannya untuk membiayai pengeluaran-pengeluaran mum berhubungan langsung dengan tugas negara untuk menyelenggarakan pemerintahan

\section{Fungsi Pajak}

Ada dua fungsi pajak (Mardiasmo, 2011:1), yaitu:

1. Fungsi Budgetair

Pajak sebagai sumber dana bagi pemerintah untuk membiayai pengeluaranpengeluarannya.

2. Fungsi mengatur (regulerend)

Pajak sebagai alat untuk mengatur dan melaksanakan kebijaksanaan pemerintah dalam bidang sosial dan ekonomi.

\section{Pajak Penghasilan}

Resmi (2011:74) Pajak Penghasilan (PPh) adalah pajak yang dikenakan terhadap Subjek Pajak atas penghasilan yang diterima atau diperolehnya dalam satu tahun pajak.

\section{Dasar Hukum}

Resmi (2011:74) Peraturan perundangan yang mengatur Pajak Penghasilan di Indonesia adalah UU No.7 Tahun 1983 yang telah disempurnakan dengan UU No. 7 Tahun 1991, UU No. 10 Tahun 1994, UU No. 17 Tahun 2000, UU No.36 Tahun 2008, Peraturan Pemerintah, Keputusan Presiden, Keputusan Menteri Keuangan, Keputusan Direktur Jendral Pajak maupun Surat Edaran Direktur Jendral Pajak.

\section{Pajak Penghasilan Pasal 21}

Resmi (2011:163) Pajak Penghasilan sehubungan dengan pekerjaan, jasa , dan kegiatan yang dilakukan oleh Wajib Pajak Orang Pribadi Subjek Pajak Dalam Negeri, yang selanjutnya disebut PPh Pasal 21, merupakan pajak atas penghasilan berupa gaji, upah, honorarium, tunjangan, dan pembayaran lain dengan nama dan dalam bentuk apapun sehubungan dengan pekerjaan atau jabatan, jasa, dan kegiatan yang dilakukan oleh Wajib Pajak Orang Pribadi Dalam Negeri.

\section{Dasar Hukum Pemotongan PPh Pasal 21}

Suhartono dan Ilyas (2010:205)

1. Pasal 21 UU Nomor 7 Tahun 1983 sebagaimana telah diubah terakhir dengan UU Nomor 36 Tahun 2008 tentang Pajak Penghasilan.

2. Peraturan Menteri Keuangan Nomor 252/PMK.03/2008 tentang Petunjuk Pelakasanaan Pemotongan Pajak atas Penghasilan Sehubungan Dengan Pekerjaan, Jasa dan Kegiatan Orang Pribadi.

3. Peraturan Direktur Jendral Pajak Nomor 31/PJ/2009 sebagaimana telah diubah terakhir dengan Nomor 57/PJ/2009 tentang Petunjuk Pelaksanaan Pemotongan, Penyetoran, dan Pelaporan Pajak Penghasilan Pasal 21 dan Pasal 26 sehubungan dengan Pekerjaan, Jasa, dan Kegiatan Orang Pribadi. 


\section{Tarif Pajak Penghasilan Orang Pribadi}

Lubis, $d k k(2010 ; 45)$ Dalam pemungutan pajak, tarif merupakan tolok ukur untuk menetepkan beban pajak, selain pembagian peghasilan kena pajak (income bracket). Undang-Undang Pajak Penghasilan menganut pendekatan tarif berbeda antara Tarif Pajak Penghasilan Terhadap Orang Pribadi maupun Badan.

1. PPh terutang dari suatu Wajib Pajak dalam satu tahun pajak untuk Wajib Pajak dalam negeri yang menjalakan usaha melalui bentuk usaha tetap (BUT) di Indonesia dihitung dengan menerapkan tarif pajak dikalikan terhadap penghasilan kena pajak.

2. Sebelum diterapkan tarif pajak, PKP tersebut terlebih dahulu dibulatkan ke bawah dalam ribuan penuh.

3. Tarif Pajak Orang Pribadi menurut Pasal 17 UU No. 36 Tahun 2008 tersebut adalah sebagai berikut:

\section{Tabel 1}

Tarif PPh Pasal 21

\begin{tabular}{lc}
\hline \multicolumn{1}{c}{ Lapisan Penghasilan Kena Pajak } & Tarif Pajak \\
\hline Sampai dengan Rp 50.000.000 & $5 \%$ \\
Di atas Rp 50.000.000 - Rp 250.000.000 & $15 \%$ \\
Di atas Rp 250.000.000 - Rp 500.000.000 & $25 \%$ \\
Di atas Rp 500.000.000 & $30 \%$ \\
\hline
\end{tabular}

Pasal 17 UU No. 36 Tahun 2008

Sumber : Irwansyah Lubis, et al I (2010:45)

SPT

Suhartono dan Ilyas (2010:56) Pasal 1 angka 11 UU KUP menegakan bahwa SPT adalah surat yang oleh WP digunakan untuk melaporkan penghitungan dan/atau pembayaran pajak, objek pajak dan/atau bukan objek pajak, dan/atau harta dan kewajiban sesuai dengan ketentuan peraturan perundang-undangan perpajakan.

\section{METODE PENELITIAN}

\section{Jenis Penelitian}

Penelitian ini menggunakan metode penelitian deskriptif yaitu berupa studi kasus dan studi pustaka. Studi kasus dilakukan pada PT. GATRA KALTIM JAYA Kota Balikpapan, sedangkan studi pustaka dilakukan dengan mengumpulkan data-data dari literatur-literatur yang relevan dengan permasalahan Pajak Penghasilan.

\section{Tempat dan Waktu Penelitian}

Pemilihan Lokasi yang dilakukan dalam penelitian ini adalah pada PT. GATRA KALTIM JAYA yang berkedudukan di Jl. Mayjend Sutoyo No. 5-6 Balikpapan. Penelitian ini dilaksanakan pada tanggal 17 - 18 Oktober 2013. Dipilihnya tempat ini sebagai lokasi penelitian dikarenakan perusahaan ini memiliki jumlah karyawan yang memadai sehingga menarik untuk dilakukan penelitian mengenai tata cara perusahaan dalam melaksanakan pemotongan, penyetoran, dan pelaporan pajak penghasilan pasal 21 pada karyawan.

\section{Prosedur Penelitian}

Prosedur yang dilakukan dalam penelitian ini adalah sebagai berikut:

1. Menentukan judul dan merumuskan masalah.

2. Mengumpulkan data sesuai permasalahan yang diangkat.

3. Pengumpulan data melalui wawancara terhadap pihak-pihak yang terkait serta pengambilan datadata pada PT.GATRA KALTIM JAYA untuk mengetahui bagaimana mekanisme perhitungan dan pelaporan $\mathrm{PPh} 21$ dan apakah perhitungan dan pemotongan serta pelaporan Pajak Penghasilan Pasal 21 pada PT. GATRA KALTIM JAYA telah sesuai dengan ketentuan Undangundang Perpajakan No. 36 Tahun 2008

4. Mengolah data dan menginterpretasikan hasil pengolahan data. 
5. Menarik kesimpulan dan memberikan saran yang dianggap perlu sebagai perbaikan dalam masalah yang ada.

\section{Jenis Data dan Sumber Data \\ Jenis Data}

Data Primer yaitu data yang diperoleh langsung dari perusahaan atau data yang terjadi di lapangan penelitian, yang diperoleh dari wawancara, observasi, dan kemudian akan diolah oleh penulis.

Data sekunder merupakan sumber data penelitian yang diperoleh peneliti secara tidak langsung melalui media perantara. Data sekunder umumnya berupa bukti, catatan atau laporan historis yang telah tersusun dalam arsip (data dokumenter) yang dipublikasikan dan yang tidak dipublikasikan.

\section{Sumber Data}

a. Data primer

Merupakan data yang diproses secara langsung dari sumbernya/langsung dari perusahaan atau data yang terjadi di lapangan penelitian, yang diperoleh dari wawancara, observasi, dan kemudian akan diolah oleh penulis.

b. Data Sekunder

Merupakan data pendukung dan pelengkap yang tidak diusahakan sendiri pengumpulannya oleh penulis/ penelitian yang diperoleh peneliti secara tidak langsung melalui media perantara. Data sekunder umumnya berupa bukti, catatan atau laporan historis yang telah tersusun dalam arsip (data dokumenter) yang dipublikasikan dan yang tidak dipublikasikan

\section{Metode Pengumpulan Data}

Adapun teknik atau cara pengumpulan data yang dilakukan penulis adalah sebagai berikut :

1. Penelitian Lapangan (Field Research)

Penelitian ini melakukan pengumpulan data dengan :

1. Teknik wawancara.

Metode wawancara adalah suatu metode pengumpulan data yang diperoleh dengan cara tanya jawab langsung dengan orang yang mempunyai hubungan langsung dengan masalah yang diteliti. Tanya jawab dilakukan terhadap staf perpajakan perusahaan.

2. Metode observasi

Metode observasi adalah suatu metode pengumpulan data dan penyimpulan data dengan cara mengadakan penelitian langsung terhadap objek penelitian.

3. Dokumentasi.

Yaitu metode pengumpulan data dengan cara mempelajari dokumen, bukti-bukti atau catatan yang berhubungan dengan objek yang diteliti. Penelitian ditujukan pada dokumen-dokumen yang berhubungan dengan data yang diperlukan. Pengumpulan data dokumentasi menggunakan alat tulis manual maupun elektronik.

\section{Metode Analisis}

Metode analisis yang digunakan dalam penelitian ini adalah penelitian deskriptif. Penelitian deskriptif yaitu suatu metode pembahasan yang sifatnya menguraikan, menggambarkan suatu keadaan atau data serta melukiskan dan menerapkan suatu keadaan sedemikian rupa sehingga dapat ditarik kesimpulan untuk menjawab permasalahan yang ada.

\section{Definisi Operasional}

Sugiyono (2010:38) mengatakan definisi operasional adalah penentuan konstruk sehingga menjadi variabel yang dapat diukur. Variabel dapat diukur dengan berbagai macam konstruk yang diwakilinya, yang dapat berupa angka atau berupa atribut yang menggunakan ukuran atau skala dalam penelitian.

1. Penghitungan Pajak Penghasilan Pasal 21 menurut Undang-Undang No. 36 Tahun 2008 adalah suatu penghitungan untuk menentukan jumlah pajak yang terutang oleh wajib pajak sesuai dengan peraturan perpajakan yang berlaku. 
2. Penyetoran Pajak Penghasilan Pasal 21 menurut Undang-Undang No. 36 Tahun 2008 adalah pembayaran pajak yang di lakukan pemotong pajak dengan menyetor pajak ke kantor pos atau bank. Penyetoran dilakukan paling lambat tanggal 10 bulan berikutnya setelah Masa Pajak berakhir.

3. Pelaporan Pajak Penghasilan Pasal 21 menurut Undang-Undang No. 36 Tahun 2008 adalah melaporkan pembayaran pajak melalui penyampaian SPT Masa PPh Pasal 21 ke Kantor Pelayanan Pajak. Pelaporan dilakukan paling lambat tanggal 20 bulan berikutnya setelah Masa Pajak berakhir.

\section{HASIL PENELITIAN DAN PEMBAHASAN}

\section{Profil Perusahaan}

Berawal pada tanggal 24 Desember 1990, manakala Bapak Hendarman Muljono bersama dengan Bapak Ignatius Yudas Tadius Suyanto mendirikan suatu perseroan Komanditer, maka berdasarkan akte No.163 yang dibuat dihadapan Adi Gunawan Sarjana Hukum, Notaris di Balikpapan, didirikan Perseroan Komanditer CV. GRAND KALTIM JAYA, maksud dan tujuan perusahaan adalah bergerak dalam bidang perdagangan Umum / Leveransir Distributor dan Dealer Kendaraan Bermotor, termasuk penjualan sparepart kendaraan bermotor serta variasinya, Agen / Perwakilan peruahasan lokal dan luar negeri, penyewaan kendaraan bermotor, pengangkutan, perbengkelan dan kontraktor.

Sebagai dealer penjualan kendaraan bermotor khususnya kendaraan roda dua, kegiatan usaha dalam bidang tersebut ternyata berkembang dengan pesat dan seiring dengan perkembangannya, perusahaan selalu berupaya untuk memberikan pelayanan yang terbaik kepada para pelanggan, maka untuk mencerminkan keinginan tersebut, pengurus perusahaan pada tanggal 15 Desember 1995 mengubah nama CV. GRAND KALTIM JAYA menjadi CV. GATRA KALTIM JAYA. Perubahan nama tersebut dilakukan berdasarkan Akta Perubahan Nomor 70, tertanggal 15 Desember 1995 dibuat dihadapan Adi Gunawan Sarjana Hukum, Notaris di Balikpapan, dan sejak itu nama CV. GATRA KALTIM JAYA dengan bidang usaha yang sama secara resmi mulai berkibar.

Sejalan dengan kemajuan perusahaan dan permintaan masyarakat terhadap kendaraan roda dua semakin meningkat ternyata pula animo masyarakat dan Perusahaan di wilayah Kota Balikpapan terhadap kebutuhan kendaraan roda empat mulai tumbuh, maka mulai tahun 1996 usaha CV. GATRA KALTIM JAYA elain menjual kendaraan roda dua, juga mulai menjual kendaraan roda empat dan juga menyewakan kendaraan roda empat serta jasa penyediaan tenaga kerja pengemudi (Labor Supply).

Bertitik tolak dari perkembangan usaha yang semakin maju dan pesat tersebut, maka CV. GATRA KALTIM JAYA yang semula berbentuk Perusahaan Komanditer (CV) ditingkatkan bentuknya menjadi Perseroan Terbatas (PT), maka berdasarkan Akta Notaris Nomor 15, tertanggal 8 Januari 2004 yang dibuat dihadapan Notaris Hengky Ribowo Sarjana Hukum, Notaris di Balikpapan, CV. GATRA KALTIM JAYA berubah menjadi PT. GATRA KALTIM JAYA, dan selanjutnya Akta terebut telah mendapat pengesahan dari Departemen Kehakiman dan Hak Asasi Manusia Republik Indonesia dengan Nomor 117, tertanggal 31 Juli 2008 yang dibuat dihadapan Notaris Rudi Muljono Sarjana Hukum, dan selanjutnya Akta tersebut telah mendapat pengesahan dari Departemen Kehakiman dan Hak Asasi Manusia Republik Indonesia dengan Nomor AHU-57647 AH.01.02. Tahun 2008 tertanggal 1 September 2008.

Sehubungan dengan perubahan tersebut maka untuk selanjutnya perusahaan memakai nama PT. GATRA KALTIM JAYA, yang berkedudukan di Balikpapan dan bilamana dipandang perlu maka perusahaan akan membuka cabang-cabang atau perwakilan di daerah lainnya, dan perseroan ini didirikan untuk jangka waktu yang tidak ditentukan lamanya.

Maksud didirikannya PT. GATRA KALTIM JAYA adalah untuk melanjutkan dan meneruskan usaha dari Perseroan Komanditer CV. GATRA KALTIM JAYA yang berkedudukan di Balikpapan.

PT. GATRA KALTM JAYA juga mengembangkan sub-divisinya terutama di bidang IT and Computer Retail. Divisi ini dibentuk pada tanggal 1 Agustus 2006 dengan dibukanya toko retail computer, GATRA KOMPUTER di Jl. Ahmad Yani Balikpapan yang menjadi kantor divisi baru PT. 
GATRA KALTIM JAYA. Sub-divisi komputer ini menangani penjualan retail, penyewaan alat-alat IT, IT konsultan sampai ke IT service maintenance.

Pada saat ini kantor pusat PT. GATRA KALTIM JAYA berdomisili dan berkantor di Jalan MayJend Sutoyo No 05/06 RT 42 Balikpapan, Telepon (0542) 422715, Faximile (0542) 733636.

\section{Hasil Penelitian}

Pajak penghasilan merupakan pajak yang dibebankan pada penghasilan perorangan, perusahaan atau badan hukum lainnya. Pegawai/karyawan adalah orang yang bekerja pada pemberi kerja, baik sebagai karyawan tetap atau karyawan tidak tetap/tenaga kerja lepas berdasarkan perjanjian atau kesepakatan kerja baik secara tertulis maupun tidak tertulis, untuk melaksanakan suatu pekerjaan dalam jabatan atau kegiatan tertentu dengan memperoleh imbalan/penghasilan yang dibayarkan berdasarkan periode tertentu, penyelesaian pekerjaan atau ketentuan lain yang ditetapkan pemberi kerja.

Penelitian ini dilakukan pada PT. GATRA KALTIM JAYA Kota Balikpapan yang adalah perusahaan yang menjadi objek penelitian penulis. Dalam penelitian ini dapat dilihat bagaimana mekanisme perhitungan dan pelaporan PPh Pasal 21 yang dilakukan oleh perusahaan terhadap gaji karyawan pada perusahaan ini. Di bawah ini disajikan tabel flowchart tentang mekanisme perhitungan dan pelaporan PPh Pasal 21 Pada PT. GATRA KALTIM JAYA Kota Balikpapan.

\section{Gambar 1}

Mekanisme Perhitungan Dan Pelaporan PPh Pasal 21 Pada PT. GATRA KALTIM JAYA

\begin{tabular}{|l|l|l} 
Pendaftaran & Perhitungan & Penyetoran dan Pelaporan \\
\hline
\end{tabular}




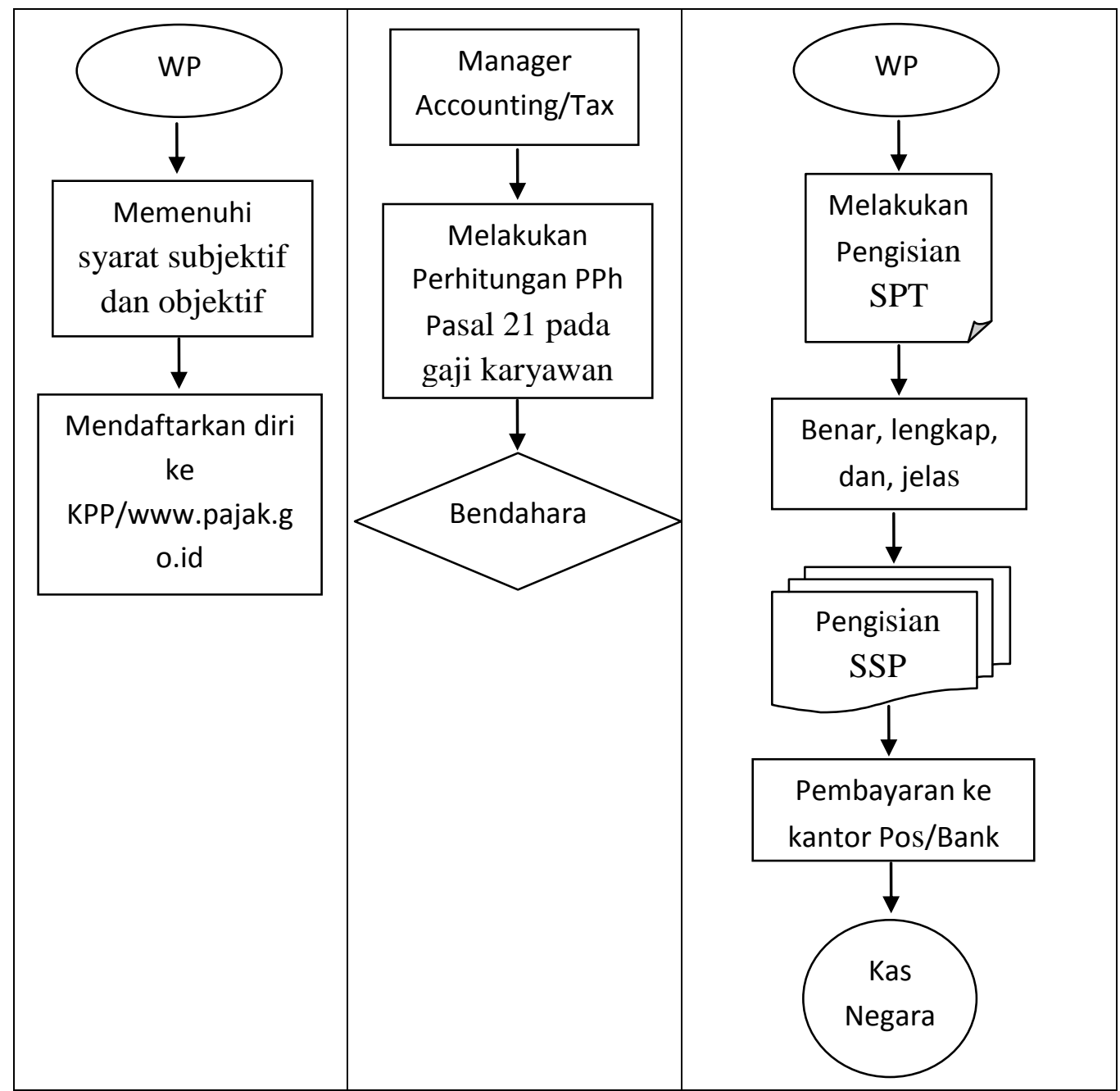

Sumber : PT. GATRA KALTIM JAYA

Deskripsi penjelasan Mekanisme Perhitungan Dan Pelaporan PPh Pasal 21 Pada PT. GATRA KALTIM JAYA:

a. Pendaftaran

1. Wajib pajak yang memenuhi syarat subjektif dan objektif mendaftarkan diri ke KPP/www.pajak.go.id

2. Menerima NPWP

b. Perhitungan

1. Manager Accounting/Tax pada peruahaan melakukan perhitungan PPh Pasal 21 terhadap gaji karyawan.

2. Setelah dihitung manager menyetor $\mathrm{PPh} 21$ ke Bendahara perusahaan

c. Penyetoran dan Pelaporan

1. Wajib pajak melakukan pengisian SPT dengan benar, lengkap, dan jelas.

2. Melakukan pengisian SSP (Surat Setoran Pajak)

3. Menyetorkan PPh Pasal 21 ke Bank/Kantor Pos

4. Wajib Pajak memperoleh tanda terima Penyampaian SPT

\section{Perhitungan PPh 21}

Berdasarkan tabel perhitungan di atas maka di bawah ini disajikan contoh rincian penjelasan mengenai perhitungan dan pelaporan PPh Pasal 21 pada karywan PT. GATRA KALTIM JAYA 
Tabel 3

Perhitungan Pajak Penghasilan Pasal 21

\begin{tabular}{|c|c|c|c|c|}
\hline Nama / Status & Teori PPh Pasal 21 & $\begin{array}{c}\text { Perhitungan PPh } \\
\text { Pasal } 21 \\
\end{array}$ & $\begin{array}{c}\text { Realisasi } \\
\text { Perusahaan }\end{array}$ & Ket. \\
\hline $\mathrm{K} / 2$ & $\begin{array}{l}\text { Penghasilan bruto } \\
\text { sebulan }- \text { biaya jabatan } \\
=\text { penghasilan neto } \\
\text { sebulan } \times 12 \text { bulan }= \\
\text { penghasilan neto } \\
\text { setahun }- \text { PTKP = PKP } \\
\text { x tarif pajak pasal } 21= \\
\text { PPh Pasal } 21 \text { setahun : } \\
12 \text { bulan = PPh Pasal } \\
21 \text { sebulan }\end{array}$ & $\begin{array}{rr}\text { Rp } & 5.746 .615 \\
\text { Rp } & 287.331 \\
\text { Rp } & 5.459 .284 \\
& \underline{12 \mathrm{bln}} \\
\text { Rp } & 65.511 .408 \\
\text { Rp } & 30.375 .000 \\
\text { Rp } & 35.708 .950 \\
& \frac{5 \%}{\text { Rp }} \\
1.756 .820 \\
\text { Rp } & 146 \text { bln } \\
46.402\end{array}$ & $\begin{array}{rr}\text { Rp } & 5.746 .615 \\
\text { Rp } & 287.331 \\
\text { Rp } & 5.459 .284 \\
& \underline{12 \mathrm{bln}} \\
\text { Rp } & 65.511 .408 \\
\text { Rp } 30.375 .000 \\
\operatorname{Rp} & 35.708 .950 \\
& 5 \% \\
\operatorname{Rp} & 1.756 .820 \\
& \underline{5 \mathrm{bln}} \\
\mathrm{Rp} & 146.402\end{array}$ & SAMA \\
\hline
\end{tabular}

Sumber : PT. GATRA KALTIM JAYA

\section{Perlakuan Akuntansi Terhadap PPh Pasal 21 atas Gaji Pegawai}

Lewat informasi yang didapatkan melalui wawancara dan data yang diperoleh dengan salah satu pegawai bidang yang menangani tentang Pajak Penghasilan Pasal 21 di PT. GATRA KALTIM JAYA wilayah Balikpapan diketahui bahwa PPh Pasal 21 atas gaji pegawai ditanggung oleh perusahaan. PT. GATRA KALTIM JAYA melakukan perhitungan dan penyetoran PPh Pasal 21 setiap bulan paling lambat tanggal 10 bulan berikutnya setelah masa pajak berakhir dan melakukan pembayaran ke Kantor Pos atau Bank dengan menggunakan Surat Setoran Pajak (SSP). Pada akhir tahun diadakan perhitungan kembali atas seluruh PPH Pasal 21 untuk 12 bulan dalam tahun tersebut, agar dapat diketahui apakah jumlah pajak yang telah disetorkan terjadi kurang bayar atau lebih bayar, sehingga dapat segera dilakukan penyesuaian dan kemudian akan dilaporkan kembali dalam SPT tahunan PPh Pasal 21.

Adapun kebijakan atau perlakuan akuntansi yang ditetapkan oleh PT. GATRA KALTIM JAYA wilayah Balikpapan atas biaya gaji pegawai dan PPh Pasal 21 adalah sebagai berikut:

Pada saat pembayaran gaji dan perhitungan PPh Pasal 21, a/n RB adalah :

Beban Gaji Rp 5.746.615

Beban PPh 21 (ditanggung)Rp 148.787

$$
\begin{array}{lrr}
\text { Hutang PPh 21 Pegawai } & \text { Rp } & 148.787 \\
\text { Kas/Bank } & & \text { Rp 5.746.615 }
\end{array}
$$

Pada saat penyetoran pajak, a/n Ranto Bastian ke Kas Negara

Hutang PPh 21

Kas/Bank

$$
\text { Rp } 148.787
$$

Rp 148.787

Penyajiannya dalam laporan keuangan khususnya Neraca, Pajak Peghasilan Pasal 21 atas gaji pegawai yang belum disetor ke Kas Negara masuk dalam kelompok Hutang Pajak, dimana Hutang $\mathrm{PPh}$ Pasal 21 digabung dengan hutang pajak lainnya seperti hutang PPh pasal 22, hutang $\mathrm{PPh}$ pasal 23, hutang PPn dan lain-lain. Namun dari informasi yang didapatkan, pihak perusahaan selalu langsung menyetorkan PPh Pasal 21 ke Kas Negara setiap bulannya, sehingga kecil kemungkinan adanya hutang PPh Pasal 21. 
Tabel 4

Penyetoran PPh Pasal 21 Ke Kas Negara

\begin{tabular}{lcl}
\hline \multicolumn{1}{c}{ SSP } & Jumlah Setoran $($ Rp) & \multicolumn{1}{c}{ Tanggal Penyetoran } \\
\hline Januari & Rp 5.003 .950 & 07 Februari 2013 \\
Februari & Rp 6.519.000 & 08 Maret 2013 \\
Maret & Rp 6.656.500 & 09 April 2013 \\
April & Rp 6.785.350 & 08 Mei 2013 \\
Mei & Rp 6.828.700 & 10 Juni 2013 \\
Juni & Rp 6.900.850 & 09 Juli 2013 \\
Juli & Rp 17.298.150 & 06 Agustus 2013 \\
Agustus & Rp 6.495.250 & 09 September 2013 \\
September & Rp 6.918.600 & 09 Oktober 2013 \\
Oktober & Rp 7.210.280 & 08 November 2013 \\
\hline
\end{tabular}

Sumber : PT. GATRA KALTIM JAYA BALIKPAPAN

\section{Pelaporan Pajak Penghasilan Pasal 21 Pada PT. GATRA KALTIM JAYA Balikpapan}

Secara keseluruhan pelaporan pajak pada PT. GATRA KALTIM JAYA Balikpapan telah tertib. Pelaporan pajak mempunyai batas tanggal jatuh tempo, yang diatur dalam Pasal 9 UU No. 28 Tahun 2007 Ketentuan Perpajakan.

PT. GATRA KALTIM JAYA telah menyetor pajak yang terutang sebelum tanggal 10 bulan takwim berikutnya dan kemudian melakukan kewajiban pelaporan sebelum tanggal 20 bulan takwim berikutnya setelah masa pajak berakhir.

\section{Pembahasan}

Evaluasi Pelaksanaan Perhitungan, Pemotongan serta Penyetoran dan Pelaporan PPh Pasal 21 Pada PT. GATRA KALTIM JAYA

Dari data yang diteliti dan diolah oleh penulis, didapati bahwa PT. GATRA KALTIM JAYA Kota Balikpapan sudah melaksanakan perhitungan dan pelaporan PPh Pasal 21 dengan baik dan sesuai dengan UU No. 36 Tahun 2008 tentang pembayaran pajak dalam tahun pajak melalui perhitungan, pemotongan dan pelaporan pajak atas penghasilan yang diterimaatau diperoleh oleh Wajib Pajak Orang Pribadi Dalam Negeri sehubungan dengan pekerjaan, jasa dan kegiatan lainnya. Di bawah ini dapat kita lihat tabel evaluasi pelaksanaan perhitungan, pemotongan serta penyetoran dan pelaporan PPh Pasal 21 Pada PT. GATRA KALTIM JAYA

\section{Tabel 5}

Evaluasi Pelaksanaan Perhitungan, Pemotongan serta Penyetoran dan Pelaporan PPh Pasal 21 Pada PT. GATRA KALTIM JAYA

\begin{tabular}{|c|c|c|}
\hline Deskripsi & Pelaksanaan & Keterangan \\
\hline Perhitungan & $\begin{array}{l}\text { Penghasilan bruto sebulan }- \text { biaya jabatan, } \\
\text { jaminan hari tua }(2 \%)=\text { penghasilan neto } \\
\text { sebulan } \times 12 \text { bulan }=\text { penghasilan neto } \\
\text { setahun }- \text { PTKP }=\text { PKP x tarif pajak pasal } \\
21=\text { PPh Pasal } 21 \text { setahun : } 12 \text { bulan }=\text { PPh } \\
\text { Pasal } 21 \text { sebulan }\end{array}$ & $\begin{array}{c}\text { Sesuai dengan Undang- } \\
\text { Undang Perpajakan yang } \\
\text { berlaku yaitu UU Nomor } 36 \\
\text { Tahun } 2008\end{array}$ \\
\hline Pemotongan & $\begin{array}{l}\text { Pemotongan PPh Pasal } 21 \text { dilakukan atas } \\
\text { penghasilan berupa pesangon, uang tebus } \\
\text { pensiun, dan tunjangan hari tua atau } \\
\text { jaminan hari tua yang pengenaannya } \\
\text { bersifat final diatur dalam Keputusan } \\
\text { Menteri Keuangan No. } \\
\text { 112/KMK.03/2001/Tanggal } 6 \text { Maret } 2001 \text {. }\end{array}$ & $\begin{array}{c}\text { Sesuai dengan Undang- } \\
\text { Undang Perpajakan yang } \\
\text { berlaku yaitu UU Nomor } 36 \\
\text { Tahun } 2008\end{array}$ \\
\hline $\begin{array}{l}\text { Penyetoran dan } \\
\text { pelaporan }\end{array}$ & $\begin{array}{l}\text { Penyetoran: } \\
-\quad \text { Ke Kas Negara melalui Kantor }\end{array}$ & $\begin{array}{l}\text { Sesuai dengan Undang- } \\
\text { Undang Perpajakan yang }\end{array}$ \\
\hline
\end{tabular}




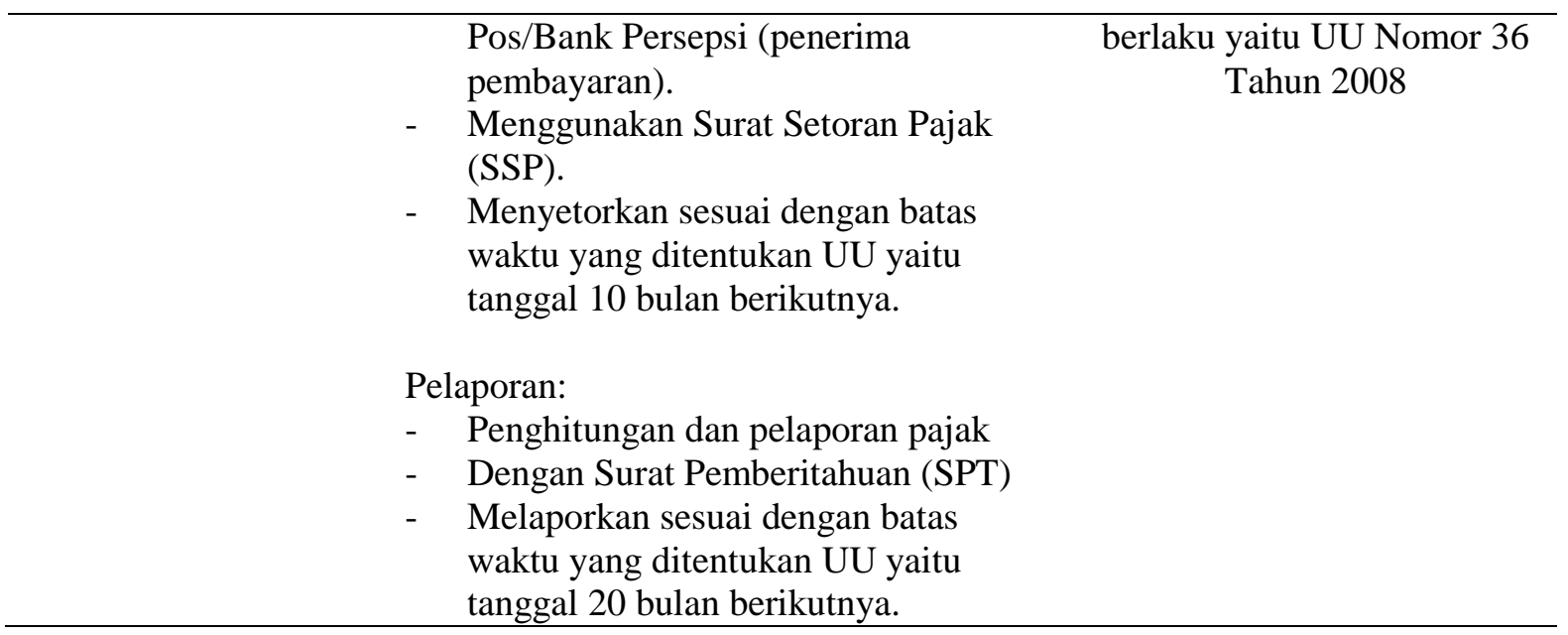

Setelah melihat tabel di atas dan dari data mengenai perhitungan, pemotongan dan pelaporan PPh 21 pada PT. GATRA KALTIM JAYA, maka mekanisme perhitungan dan pelaporan PPh Pasal 21 pada PT. GATRA KALTIM JAYA telah sesuai dengan peraturan perpajakan yang berlaku dalam hal ini UU Nomor 36 Tahun 2008 dan PSAK No. 46 tentang akuntansi Pajak Penghasilan.

\section{Kesimpulan}

\section{PENUTUP}

Berdasarkan dari hasil penelitian dan data yang diperoleh, maka penulis dapat mengambil keimpulan bahwa :

1. PT. GATRA KALTIM JAYA Balikpapan dalam melakukan perhitungan Pajak Penghasilan $(\mathrm{PPh})$ Pasal 21 atas karyawan tetap telah sesuai dengan ketentuan Undang-Undang No. 36 Tahun 2008 tentang Pajak Penghasilan.

2. Pelaporan PPh Pasal 21 yang dicatatkan oleh Staff Accounting pada PT. GATRA KALTIM JAYA Balikpapan telah dilaksanakan dengan tepat waktu sesuai dengan Undang-Undang No. 36 Tahun 2008 tentang Pajak Penghasilan.

3. Pelaksanaan PPh Pasal 21 pada PT. GATRA KALTIM JAYA Balikpapan telah sesuai dengan Keputusan Direktur Jendral Pajak No. KEP-545/PJ/2000 seagaimana telah diubah dengan Peraturan Jendral Pajak No. 15/PJ/2006 tentang pelaksanaan pemotongan, penyetoran dan pelaporan PPh Pasal 21 sehubungan dengan pekerjaan jasa dan kegiatan orang pribadi.

\section{Saran}

Adapun saran-saran yang perlu penulis sampaikan adalah sebagai berikut:

1. Pihak perusahaan harus peka terhadap setiap perubahan-perubahan peraturan perpajakan.

2. Pihak perusahaan tidak perlu takut dalam memberikan data-data atau informasi-informasi yang dibutuhkan oleh para peneliti, karena peneliti hanya membandingkan antara teori dan prakteknya dilapangan. Apabila ditemukan kekeliruan, peneliti hanya dapat memberikan informasi dimana letak kekeliruan tersebut.

3. Pihak perusahaan hendaknya dengan senang hati menerima para peneliti untuk melakukan riset di perusahaannya, karena perusahaan akan memperoleh informasi-informasi yang baru seputar objek yang diteliti. 


\section{DAFTAR PUSTAKA}

Harahap,Sofyan Syafri. 2005. Teori Akuntansi. PT. Raja Grafindo Persada. Jakarta.

Belkaoui, Ahmed Riahi. 2011. Teori Akuntansi. Salemba Empat. Jakarta.

Waluyo. 2009, Akuntansi Pajak. Salemba Empat. Jakarta.

Resmi Siti. 2011. Perpajakan Teori Dan Kasus. Salemba Empat, Jakarta.

Waluyo. 2011. Perpajakan Indonesia . Salemba Empat. Jakarta.

Irwansyah Lubis. Gustian Djuanda, Ardiansyah Lubis. 2010. Review Pajak Orang Pribadi Dan Orang Asing. Salemba Empat. Jakarta.

Mardiasmo. 2011 , Perpajakan. Andi. Yogyakarta.

Mardiasmo. 2009. Perpajakan. Andi. Yogyakarta.

Rahayu Siti. 2010. Perpajakan Indonesia. Graha Ilmu. Yogyakarta.

Suhartono Rudy, Ilyas B. Wirawan. 2010. Ensiklopedia Perpajakan Indonesia. Salemba Empat. Jakarta.

Suhartono Rudy, Ilyas B. Wirawan . 2010. Ketentuan Umum dan Tata Cara Perpajakan. Salemba Empat. Jakarta.

Weygandt, Kimmel, Kieso. 2011. Financial Accounting. IFRS Edition. Courier Kendallville. United States of America.

Sugyono. 2010. Metode Penelitian dan Bisnis. Alfabeta. Bandung.

Ilyas B. Wirawan, Richard Burton. 2010. Hukum Pajak. Salemba Empat. Jakarta 